\title{
INTEGRASI TRUST DAN TECHNOLOGY ACCEPTANCE MODEL (TAM) DALAM INTENTION TO TRANSACT \\ (Studi pada Konsumen Pengguna Tokopedia)
}

\section{INTEGRATION OF TRUST AND TECHNOLOGY ACCEPTANCE MODEL (TAM) INSIGHT INTENTION TO TRANSACT (Study on Tokopedia Consumers)}

\author{
Budiyanto $^{1)}$ \& Dewi Pangestuning Utami ${ }^{2)}$ \\ ${ }^{1,2)}$ Fakultas Ekonomi Universitas Muhammadiyah Purworejo \\ Jl. Pahlawan KM. 3, Sucenjurutengah, Bayan, Purworejo 54224 \\ budiyanto@umpwr.ac.id,dewipangestuuu@gmail.com
}

\begin{abstract}
ABSTRAK
Teknologi yang semakin maju membuat berbelanja online terus berkembang dari waktu ke waktu. Cara berbelanja yang mudah, simpel, bahkan konsumen dapat mendapatkan harga yang lebih murah dibanding dengan toko-toko tradisional memang menjadi pilihan tersendiri bagi konsumen. Kecepatan internet yang sangat tinggi turut mendukung pesatnya bisnis e-commerce di Indonesia. Tujuan dari penelitian ini adalah 1) pengaruh trust terhadap perceived usefulness, 2) pengaruh trust terhadap perceived ease of use, 3) pengaruh trust terhadap perceived risk, 4) pengaruh trust terhadap intention to transact, 5) pengaruh perceived usefulness terhadap intention to transact, 6) pengaruh perceived ease of use terhadap intention to transact dan 7) pengaruh perceived risk terhadap intention to transact. Populasi dalam penelitian ini adalah seluruh konsumen pengguna marketplace tokopedia. Sampel penelitian ini berjumlah 120 orang. Teknik sampling yang digunakan dalam penelitian ini yaitu purposive sampling. Pegujian hipotesis yang digunakan regresi linier berganda. Hasil penelitian menunjukkan bahwa 1) trust berpengaruh positif signifikan terhadap perceived usefulness, 2) trust berpengaruh positif signifikan terhadap perceived ease of use, 3) trust berpengaruh negatif signifikan terhadap perceived risk, 4) trust berpengaruh positif signifikan terhadap intention to transact, 5) perceived usefulness berpengaruh positif signifikan terhadap intention to transact, 6) perceived ease of use berpengaruh positif signifikan terhadap intention to transact, 7) perceived risk negatif signifikan terhadap intention to transact.
\end{abstract}

Kata Kunci: trust, perceived usefulness, perceived ease of use, perceived risk, intention to transact, tokopedia

\begin{abstract}
Increasing advanced technology makes online shopping continue to grow from time to time. An easy, simple way to shop, and even consumers can get cheaper prices compared to traditional shops, is indeed a choice for consumers. Very high internet speed also supports the rapid ecommerce business in Indonesia. The purposes of this study is 1) the effect of trust on perceived usefulness, 2) the effect of trust on perceived ease of use, 3) the effect of trust on perceived risk, 4) the effect of trust on intention to transact, 5) the effect of perceived usefulness on intention to transact, 6) the effect of perceived ease of use on the intention to transact and 7) the effect of perceived risk on the intention to transact.
\end{abstract}

Budiyanto \& Dewi Pangestuning Utami; Integrasi Trust dan Technology Acceptance Model (TAM) dalam Intention to Transact 


\section{SEGMEN Jurnal Manajemen dan Bisnis \\ Volume 17 No 2 Juli 2021 \\ p-ISSN: 0216-938X e-ISSN: 2684-8414}

Population in this study is all consumers who use Tokopedia marketplace. The sample of this study amounted to 120 people. The sampling technique used in this research is purposive sampling. Testing the hypothesis used multiple linear regression. The results show that 1) trust has a significant positive effect on perceived usefulness, 2) trust has a significant positive effect on perceived ease of use, 3) trust has a significant negative effect on perceived risk, 4) trust has a significant positive effect on intention to transact, 5) perceived usefulness has a significant positive effect on intention to transact, 6) perceived ease of use has a significant positive effect on intention to transact, 7) perceived risk is significant negative on intention to transact.

Keywords: trust, perceived usefulness, perceived ease of use, perceived risk, intention to transact, tokopedia

\section{PENDAHULUAN}

Gaya hidup serba instan ini sudah menjadi kebiasaan masyarakat pada umumnya ingin serba praktis dan cepat dalam mendapatkan sesuatu. Masyarakat lebih mudah untuk membeli dan mendapatkan apa yang diinginkannya tanpa menghabiskan banyak waktu, uang dan tenaga (www.kompasiana.com). Berbelanja online juga memiliki risiko yang harus diperhatikan sehingga risiko tersebut dapat diminimalisir dan membuat belanja online tetap aman dan nyaman (www.tribunnews.com).

Berdasarkan hasil survey dari Sharing Vision tahun 2019 menyebutkan, 64\% konsumen online adalah generasi milenial, menikah, dan bekerja. Sementara Badan Perencanaan Pembangunan Nasional (Bappenas) memprediksi, saat ini jumlah generasi milenial Indonesia mencapai 90 juta jiwa (www.pikiranrakyat.com). Selain generasi milenial, Pertumbuhan yang pesat di sektor e-commerce ini dipicu oleh adopsi teknologi yang cepat oleh masyarakat Indonesia. Tingkat penetrasi internet dan penggunaan ponsel pintar yang tinggi menjadi pemicu kebiasaan berbelanja online. Kecepatan internet yang sangat tinggi turut mendukung pesatnya bisnis $e$ commerce di Indonesia (www.cnbcindonesia.com).
Di Indonesia sendiri terdapat $10 e$ commerce jenis marketplace dengan pengunjung terbanyak menurut (www.inews.id) yaitu tokopedia, shopee, bukalapak, lazada, blibli.com, jd.id, orami, bhinneka, sociolla, dan zalora. E-commerce menjadi salah satu industri yang memiliki pertumbuhan positif dari tahun ke tahun. Sebab, industri ini memberikan kemudahan dalam pembelian dan kecepatan dalam berbelanja (www.merdeka.com).

Titik tertentu dalam proses pembelian adalah konsumen mencari dan mengevaluasi informasi tentang merek yang diinginkan, sebagai hasil dari evaluasi tersebut konsumen dapat mengembangkan niat beli atau kecenderungan untuk membeli merek tertentu (Belch and Belch, 2003:120). Menurut (Fisbein dan Ajzen, 1975:288) niat digambarkan sebagai situasi seseorang sebelum melakukan suatu tindakan yang dapat dijadikan dasar untuk memprediksi perilaku atau tindakan tersebut. Menurut Belch and Belch (2003:120) niat beli adalah kecenderungan untuk membeli sebuah merek dan secara umum berdasarkan kesesuaian antara motif pembelian dengan atribut atau karakteristik merek yang dapat dipertimbangkan. Menurut Pavlou (2002) niat untuk bertransaksi secara luas digambarkan sebagai niat konsumen untuk terlibat dalam elektronik yaitu pertukaran hubungan dengan pengecer website, seperti

Budiyanto \& Dewi Pangestuning Utami; Integrasi Trust dan Technology Acceptance Model (TAM) dalam Intention to Transact 


\section{SEGMEN Jurnal Manajemen dan Bisnis \\ Volume 17 No 2 Juli 2021 \\ p-ISSN: 0216-938X e-ISSN: 2684-8414}

berbagi informasi bisnis, memelihara hubungan bisnis, dan melakukan transaksi bisnis.

Berdasarkan konteks niat untuk bertransaksi, maka penelitian ini didasarkan pada teori Davis (1986) yaitu Theory Acceptance Model (TAM). TAM merupakan teori yang menjelaskan mengenai pengaruh penggunaan teknologi terhadap niat berperilaku aktual. Teori ini sebelumnya mengadopsi dari teori Fishbein and Ajzen (1975) mengenai The Theory of Reasoned Action (TRA) yang menjabarkan mengenai faktor pembentuk niat perilaku. TAM menyatakan bahwa keinginan untuk menggunakan suatu sistem dipengaruhi oleh dua faktor penentu utama, yaitu perceived usefulness dan perceived ease of use (Venkatesh dan Davis, 2000).

Davis (1989) menyatakan bahwa perceived usefulness atau persepsi manfaat yang dirasakan dapat dijelaskan sejauh mana sebuah sistem tertentu dapat meningkatkan kinerja seseorang. Dalam konteks niat untuk bertransaksi, Menurut Pavlou (2002) perceived usefulness didefinisikan sebagai sejauh mana konsumen percaya bahwa berhubungan dengan teknologi tertentu akan memfasilitasi proses transaksi. Menurut Wen, et al., (2011) perceived usefulness adalah sejauh mana konsumen merasakan bahwa berbelanja di toko berbasis website akan meningkatkan pengalaman berbelanja. Penerapan konsep perceived usefulness konsumen berpersepsi dengan adanya perdagangan e-commerce dapat mempermudah dalam proses pembelian orang-orang yang mudah menggunakannya, berguna, dan menyenangkan dapat meningkatkan berbelanja online (Rizwan, et al., 2014). Menurut Kim, et al., (2007) dalam penelitiannya menyatakan konsumen internet melaporkan bahwa mereka melakukan pembelian disitus web karena adanya perceived benefit (misalnya, kenyamanan meningkat, penghematan biaya, penghematan waktu, peningkatan berbagai produk untuk memilih dibandingkan dengan belanja secara tradisional).

Davis (1989) perceived ease of use atau persepsi kemudahan penggunaan merupakan kepercayaan seseorang dimana dalam penggunaan suatu teknologi dapat dengan mudah digunakan dan dipahami. Menurut (Hu, et al., 2009) perceived ease of use mengacu pada tingkat kemudahan dan kenyamanan ketika konsumen belanja online. Menurut Pavlou (2002) perceived ease of use didefinisikan sebagai sejauh mana konsumen percaya berhubungan dengan teknologi tertentu akan bebas dari usaha. Diterapkan pada perilaku konsumen online, berhubungan dengan website dianggap dapat memfasilitasi proses transaksi karena mudah dioperasikan dan cenderung memicu niat transaksi konsumen. Menurut Wen, et al., (2011), perceived ease of use didefinisikan sebagai sejauh mana konsumen merasakan kemudahan interaksi dengan situs website dan dapat menerima informasi yang dibutuhkan, Seperti desain antarmuka (pratinjau, kecepatan unduh dan kenyaman pencarian informasi), proses pengoprasian yang mudah, menigkatkan keefektifan pelanggan dalam mempengaruhi perilaku belanja online (Lai and Wang, 2012).

Menurut Bhatnagar, et al., (2000) mengemukakan, internet dianggap sebagai media belanja berisiko. Jika konsumen berfikir berbelanja online sangat berisiko,

Budiyanto \& Dewi Pangestuning Utami; Integrasi Trust dan Technology Acceptance Model (TAM) dalam Intention to Transact 


\section{SEGMEN Jurnal Manajemen dan Bisnis \\ Volume 17 No 2 Juli 2021 \\ p-ISSN: 0216-938X e-ISSN: 2684-8414}

maka mereka berharap adanya perbedaan dalam melakukan belanja online. Persepsi risiko didefinisikan sebagai ketidakpastian yang dirasakan dalam situasi pembelian. Jika suatu teknologi gagal dalam memberikan hasil yang diharapkan, maka akan menghasilkan kerugian bagi pengguna seperti, finansial, psikologis, fisik, atau sosial (Im, et al., 2007). Ketika memproses informasi online, konsumen sering menganggap bahwa ada risiko yang tinggi walaupun tingkat risiko sebenarnya rendah (Mukherjee dan Nath, 2003). Karena pengetahuan yang dimiliki satu sama lain, konsumen lebih baik dalam memperkirakan kemungkinan tindakan yang terjadi, sehingga mengurangi rasa ketidakpastian pada risiko (Ba, 2001). Menurut (Lui and Jamieson, 2003), dalam penelitiannya mengusulkan adanya hubungan negatif antara risiko yang dirasakan konsumen dalam menggunakan sistem dan niat pelanggan untuk bertransaksi dengan sistem. Sedangkan menurut Pavlou (2002) ketika terlibat dalam transaksi online, konsumen berhak khawatir tentang berbagai jenis risiko yang ada. Risiko yang dirasakan didefinisikan sebagai harapan subyektif konsumen untuk mendapatkan kerugian dalam mengejar hasil yang diinginkan. Risiko yang dirasakan menggambarkan ekspektasi konsumen mengenai penjual untuk terlibat dalam perilaku selama bertransaksi. Faktanya, menurut (Jarvenpaa, et al., 2000 dalam Pavlou, 2002) menyatakan bahwa pengurangan risiko yang terkait dengan pembelian dari toko internet kemungkinan akan meningkatkan kemungkinan pembelian oleh konsumen dari toko itu yang secara tidak langsung mempengaruhi niat untuk bertransaksi.
Tokopedia merupakan perusahaan teknologi Indonesia dengan misi mencapai pemerataan ekonomi digital. Tokopedia resmi diluncurkan ke public pada 17 Agustus 2009 dibawah naungan PT. Tokopedia yang didirikan oleh William Tanuwijaya dan Leontinus Alpha Edison pada 6 Februari 2009. Sejak resmi diluncurkan, PT. Tokopedia berhasil menjadi salah satu perusahaan internet Indonesia dengan pertumbuhan yang sangat pesat. Tokopedia merupakan bisnis marketplace terdepan di Indonesia yang menyediakan pilihan produk paling beragam di Indonesia. Dengan bekerjasama lebih dari 7,8 juta penjual dan 250 juta produk diantaranya barang elektronik, peralatan kantor dan rumah tangga, peralatan olahraga, kosmetik, perlengkapan bayi, fashion dll. Selain itu juga tokopedia menyediakan berbagai produk digital yang dapat memudahkan konsumen yaitu toko cash, tiket kereta api, air PDAM, angsuran kredit, pascabayar, gas PGN, mitra toppers, pulsa, BPJS, Telkom, donasi, voucher game, dan masih banyak lagi (www.tokopedia.com). dengan adanya hal tersebut konsumen berpersepsi bahwa adanya manfaat yang dirasakan dengan menggunakan marketplace tokopedia.

Tokopedia sering memberikan promo gratis ongkos kirim, diskon, flash sale atau voucher-voucher lainnya yang dapat memengaruhi sikap konsumen dalam belanja online karena terdapat manfaat untuk lebih hemat dalam berbelanja. selain itu juga, hampir semua yang dijual dapat dengan mudah ditemukan disitus jual beli tokopedia. hal ini tentu akan sangat memudahkan para pembeli yang tidak mempunyai waktu luang untuk berbelanja

Budiyanto \& Dewi Pangestuning Utami; Integrasi Trust dan Technology Acceptance Model (TAM) dalam Intention to Transact 


\section{SEGMEN Jurnal Manajemen dan Bisnis \\ Volume 17 No 2 Juli 2021 \\ p-ISSN: 0216-938X e-ISSN: 2684-8414}

ditoko. Tokopedia dilengkapi dengan fitur mesin pencari atau search engine yang memudahkan pembeli dalam menentukan dan mencari barang yang diinginkan. Tokopedia juga dilengkapi dengan fitur-fitur direktori sebagai katalog belanja. Dalam proses pengiriman barang tokopedia juga bekerja sama dengan agen pengiriman barang di Indonesia yang memudahkan pembeli yang berlokasi cukup jauh. Pembayaran juga tidak perlu khawatir karena ada proses verifikasi pembayaran yang instan, yang menguntungkan penjual dalam mengirim barang dan memuaskan pembeli karena barang bisa cepat sampai.

Berdasarkan latar belakang tersebut dapat diketahui berbagai strategi dilakukan oleh tokopedia dengan menciptakan sebuah marketplace yang dibuat sebaik mungkin agar dapat bermanfaat dan memudahkan penggunaan konsumen serta mengurangi risiko yang dirasakan konsumen dan mendorong niat untuk bertransaksi pada marketplace tokopedia.

\section{INTENTION TO TRANSACT}

Menurut Fishbein dan Ajzen (1975:288) niat adalah keinginan seseorang yang melibatkan hubungan antara dirinya dengan beberapa tindakan. Niat dapat diartikan juga sebagai indikasi keinginan seseorang untuk melakukan perilaku tertentu. Penjelasan mengenai niat beli mengacu pada model of consumer behavior, yang menjelaskan bahwa sebelum seseorang melakukan keputusan pembelian (purchase decision) terlebih dahulu diawali dengan adanya niat beli, yaitu keinginan untuk membeli merek yang paling disukai (Kotler dan Keller, 2012: 170).
Menurut Belch and Belch (2003:120) niat beli adalah kecenderungan untuk membeli sebuah merek dan secara umum berdasarkan kesesuaian antara motif pembelian dengan atribut atau karakteristik merek yang dapat dipertimbangkan. Diperjelas oleh Kinnier and Taylor (1987:310) niat beli merupakan bagian dari komponen perilaku yaitu kecenderungan responden untuk bertindak sebelum keputusan membeli benar-benar dilaksanakan.

Menurut Pavlou (2002) niat untuk bertransaksi secara luas digambarkan sebagai niat konsumen untuk terlibat dalam elektronik yaitu pertukaran hubungan dengan pengecer website, seperti berbagi informasi bisnis, memelihara hubungan bisnis, dan melakukan transaksi bisnis. Penerapan e-commerce mengaruskan konsumen menggunakan situs website untuk menerima dan memberikan informasi dan menyelesaikan pembelian produk.

Secara luas, e-commerce didefinisikan sebagai hubungan pertukaran online antara konsumen dan perusahaan online atau pemasok. Penelitian ini mempertimbangkan niat untuk bertransaksi dalam e-commerce, yang terdiri dari membeli barang atau jasa dari pemasok website (Gurung, 2006:15). Faktor utama yang menarik bagi pemasok website adalah perilaku konsumen, khususnya kesediaan mereka untuk bertransaksi dengan pemasok melalui website. Niat perilaku didefinisikan sebagai niat konsumen untuk terlibat dalam tiga perilaku khusus yaitu, mengikuti saran dari pemasok website, berbagi informasi pribadi dengan pemasok dan membeli barang atau jasa dari pemasok (McKnight, et al., 2002). Perilaku belanja online adalah perilaku

Budiyanto \& Dewi Pangestuning Utami; Integrasi Trust dan Technology Acceptance Model (TAM) dalam Intention to Transact 


\section{SEGMEN Jurnal Manajemen dan Bisnis \\ Volume 17 No 2 Juli 2021 \\ p-ISSN: 0216-938X e-ISSN: 2684-8414}

individu untuk membeli secara online. Orang yang mudah menggunakannya, bermanfaat dan menyenangkan dapat menyetujui berbelanja online (Rizwan, et al., 2014).

\section{TRA (Theory of Reasoned Action)}

TRA merupakan suatu model yang dipelajari secara luas dari psikologi sosial yang berkaitan dengan penentu perilaku (Ajzen dan Fishben, 1980, Fishben dan Ajzen, 1975 dalam Davis, Bagozzi, and Paul, 1989). Menurut TRA, kinerja seseorang dari perilaku tertentu ditentukan oleh perilakunya. Niat (behavioral intention) untuk melakukan perilaku, dan secara Bersama-sama ditentukan oleh sikap seseorang (attitude) dan norma subjektif (subjective norm) mengenai perilaku yang dimaksud (Davis, Bagozzi, and Paul, 1989).

\section{TRUST}

Trust adalah ciri khas dari sebagian besar interaksi ekonomi dan sosial yang tidak pasti. Semua interaksi membutuhkan elemen trust, terutama yang dilakukan di lingkungan e-commerce yang tidak pasti (Ba dan Pavlou, 2002; Lee, 1998). Trust telah lama dianggap sebagai katalisator dalam hubungan antara konsumen dan pemasar karena mampu memberikan ekspektasi transaksi yang berhasil. Trust selalu menjadi elemen penting dalam mempengaruhi perilaku konsumen dan telah terbukti memiliki tingkat signifikansi dalam lingkungan yang tidak pasti, seperti itu sebagai konteks e-commerce (Gefen dan Straub, 2002; Jarvenpaa dan Tractinsky, 1999; Moon dan Kim, 2002). Kurangnya kepercayaan menjadi salah satu alasan utama konsumen tidak terlibat dalam e- commerce (Keen, 1999). Dengan demikian orang mungkin berpendapat bahwa pentingnya trust telah meningkat dalam $e$ commerce karena tingkat ketidakpastian yang tinggi di sebagian besar transaksi online (Fung dan Lee, 1999). Keen (1999), berpendapat bahwa trust adalah dasar dari $e$ commerce, dengan fokus pada implikasi strategis dari kepercayaan untuk hubungan konsumen dan pemasar.

Hoffman et al., (1999) berpendapat bahwa kurangnya trust menghalangi konsumen untuk terlibat dalam transaksi online karena mereka tidak mungkin bertransaksi dengan web retailer yang gagal menyampaikan rasa kepercayaannya, terutama karena ketakutan akan oportunisme dan kekhawatiran tentang pemanfaatan infrastruktur intemet. Secara umum, hubungan yang diusulkan antara trust dan attitude dibenarkan oleh menempatkan trust dalam konteks TRA sebagai keyakinan perilaku (Sheppard, 1988).

\section{TAM (Technology Acceptence Model)}

TAM diperkenalkan oleh (Davis, 1986) merupakan adaptasi dari TRA yang dirancang khusus untuk memodelkan penerimaan pengguna terhadap sistem informasi. Sama halnya dengan TRA, TAM adalah penggunaan yang ditentukan oleh niat untuk menggunakan (intention to use) dan dipandang secara bersama-sama ditentukan oleh sikap menggunakan (attitude toward using) (Davis, Bagozzi, and Paul, 1989). TAM menyatakan bahwa keinginan untuk menggunakan suatu sistem dipengaruhi oleh dua faktor penentu utama, yaitu perceived usefulness dan perceived ease of use (Venkatesh and Davis, 2000). 


\section{SEGMEN Jurnal Manajemen dan Bisnis \\ Volume 17 No 2 Juli 2021 \\ p-ISSN: 0216-938X e-ISSN: 2684-8414}

a. Perceived usefulness

Menurut Davis (1989) menyatakan bahwa perceived usefulness atau persepsi manfaat yang dirasakan dapat dijelaskan sejauh mana sebuah sistem tertentu dapat meningkatkan kinerja seseorang. Dalam konteks pembelian online, Menurut Wen, et al., (2011) perceived usefulness adalah sejauh mana konsumen merasakan bahwa berbelanja di toko berbasis website akan meningkatkan pengalaman berbelanja.

Menurut Pavlou (2002) perceived usefulness didefinisikan sebagai sejauh mana konsumen percaya bahwa berhubungan dengan teknologi tertentu akan memfasilitasi proses transaksi. Sedangkan Menurut Lai and Wang (2012) perceived usefulness sebagai tingkat kesederhanaan yang dirasakan konsumen selama menggunakan website, manfaat yang dirasakan berarti seberapa banyak bantuan yang diterima konsumen selama menggunakan website.

Penerapan konsep perceived usefulness konsumen berpersepsi dengan adanya perdagangan e-commerce dapat mempermudah dalam proses pembelian orang-orang yang mudah menggunakannya, berguna, dan menyenangkan dapat meningkatkan berbelanja online (Rizwan, et al., 2014). Menurut Kim, et al., (2007) dalam penelitiannya menyatakan konsumen internet melaporkan bahwa mereka melakukan pembelian disitus web karena adanya perceived benefit (misalnya, kenyamanan meningkat, penghematan biaya, penghematan waktu, peningkatan berbagai produk untuk memilih dibandingkan dengan belanja secara tradisional). b. Perceived Ease of Use

Menurut Davis (1989) menyatakan bahwa perceived ease of use atau persepsi kemudahan merupakan kepercayaan seseorang dimana dalam penggunaan suatu teknologi dapat dengan mudah digunakan dan dipahami. Rizwan, et al., (2014) mendeskripsikan perceived ease of use sebagai penyebaran individu dalam membuat suatu pekerjaan akan mempermudah dalam sebuah usaha.

Menurut Pavlou (2002) perceived ease of use didefinisikan sebagai sejauh mana konsumen percaya berhubungan dengan teknologi tertentu akan bebas dari usaha. Diterapkan pada perilaku konsumen online, berhubungan dengan website dianggap dapat memfasilitasi proses transaksi karena mudah dioperasikan dan cenderung memicu niat transaksi konsumen.

Menurut Wen, et al., (2011) perceived ease of use didefinisikan sebagai sejauh mana konsumen merasakan kemudahan interaksi dengan situs website dan dapat menerima informasi yang dibutuhkan. Perceived ease of use mengindikasikan bahwa toko online mampu memenuhi kebutuhan konsumen akan kemudahan untuk pencarian informasi maupun kemudahan bertransaksi. Sedangkan menurut ( $\mathrm{Hu}$, et al., 2009) perceived ease of use mengacu pada tingkat kemudahan dan kenyamanan ketika konsumen belanja online, seperti desain antarmuka (pratinjau, kecepatan unduh dan kenyaman pencarian informasi), proses pengoprasian yang mudah, menigkatkan keefektifan pelanggan dalam mempengaruhi perilaku belanja online (Lai and Wang, 2012).

Budiyanto \& Dewi Pangestuning Utami; Integrasi Trust dan Technology Acceptance Model (TAM) dalam Intention to Transact 


\section{SEGMEN Jurnal Manajemen dan Bisnis \\ Volume 17 No 2 Juli 2021 \\ p-ISSN: 0216-938X e-ISSN: 2684-8414}

\section{PERCEIVED RISK}

Menurut Schiffman dan Kanuk (2008: 474), risiko yang dirasakan merupakan tingkat ketidakpastian atau kekhawatiran mengenai konsekuensi suatu pembelian yang dirasakan konsumen ketika mempertimbangkan pembelian suatu produk baru. Konsumen mengalami ketidakpastian ketika mereka khawatir bahwa suatu produk tidak akan bekerja sebagaimana mestinya atau memberikan alternatif penggunaan lain. Menurut Peter dan Ryan (1976) risiko yang dirasakan didefinisikan sebagai ekspektasi atas kerugian yang terkait dengan pembelian.

Menurut Bhatnagar, et al., (2000) mengemukakan, internet dianggap sebagai media belanja berisiko. Jika konsumen berfikir berbelanja online sangat berisiko, maka mereka berharap adanya perbedaan dalam melakukan belanja online. Persepsi risiko didefinisikan sebagai ketidakpastian yang dirasakan dalam situasi pembelian. Jika suatu teknologi gagal dalam memberikan hasil yang diharapkan, maka akan menghasilkan kerugian bagi pengguna seperti, finansial, psikologis, fisik, atau sosial (Im, et al., 2007). Sedangkan menurut (Featherman and Pavlou, 2003), mendefinisikan risiko yang dirasakan sebagai potensi kerugian dalam mengejar hasil yang diinginkan dalam menggunakan layanan elektronik.

Menurut Pavlou (2002) ketika terlibat dalam transaksi online, konsumen berhak khawatir tentang berbagai jenis risiko yang ada. Risiko yang dirasakan didefinisikan sebagai harapan subyektif konsumen untuk mendapatkan kerugian dalam mengejar hasil yang diinginkan. Risiko yang dirasakan menggambarkan ekspektasi konsumen mengenai penjual untuk terlibat dalam perilaku selama bertransaksi. Faktanya, menurut (Jarvenpaa, et al., 2000 dalam Pavlou, 2002) menyatakan bahwa pengurangan risiko yang terkait dengan pembelian dari toko internet kemungkinan akan meningkatkan kemungkinan pembelian oleh konsumen dari toko itu yang secara tidak langsung mempengaruhi niat untuk bertransaksi.

Sedangkan menurut Lim (2003) perceived risk didefinisikan sebagai sejauh mana konsumen percaya bahwa jika mereka membeli produk atau layanan melalui internet akan mendapatkan kerugian. Terdapat empat sumber risiko yang dirasakan konsumen terkait dengan belanja online diantaranya yaitu:

a. Risiko teknologi, mengacu pada sejauh mana individu percaya bahwa jika mereka membeli produk atau layanan melalui internet mereka akan mendapatkan kerugian yang disebabkan oleh internet dan teknologi terkait.

b. Risiko penjual, mengacu pada sejauh mana individu percaya bahwa jika mereka membeli produk atau layanan melalui internet akan mendapatkan kerugian yang disebabkan oleh penjual internet.

c. Risiko konsumen, mengacu pada sejauh mana individu percaya bahwa jika mereka membeli produk atau layanan melalui internet mereka akan mendapatkan kerugian tekanan sosial. Tekanan sosial mengacu pada tekanan yang diterima individu dari keluarga maupun teman.

d. Risiko produk, mengacu pada sejauh mana individu percaya bahwa jika mereka membeli produk atau layanan

Budiyanto \& Dewi Pangestuning Utami; Integrasi Trust dan Technology Acceptance Model (TAM) dalam Intention to Transact 


\section{SEGMEN Jurnal Manajemen dan Bisnis \\ Volume 17 No 2 Juli 2021 \\ p-ISSN: 0216-938X e-ISSN: 2684-8414}

melalui internet akan mendapatkan kerugian yang disebabkan oleh produk.

Untuk itu konsumen terlebih dahulu mencari informasi mengenai produk dan golongan produk melalui komunikasi dari mulut ke mulut, dari tenaga penjual dan dari media umum. Semakin banyak informasi yang diperoleh konsumen mengenai produk dan golongan produk, semakin dapat diramalkan konsekuensi yang mungkin timbul, dan dengan demikian semakin rendah risiko yang dirasakan (Schiffman dan Kanuk, 2008: 172).

TAM

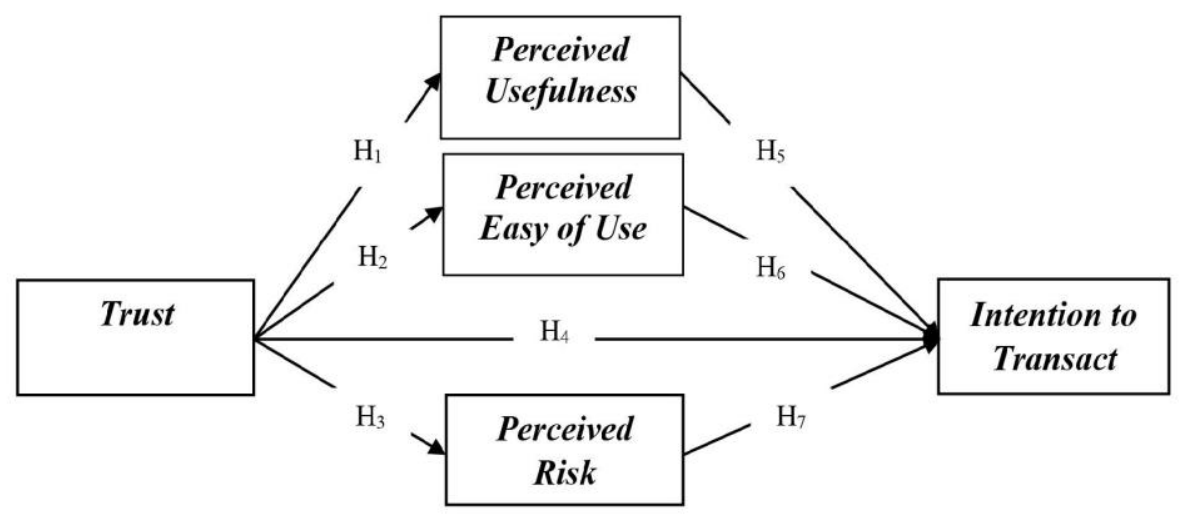

Gambar 1.

Kerangka Pikir

\section{RUMUSAN HIPOTESIS}

a. Hubungan Trust dengan TAM

Model penerimaan teknologi berasal dari teori reasonable action (TRA). TAM bisa dianggap sebagai kasus khusus dengan teori dua keyakinan. Chircu, Davis, dan Kauffman (2000), mengintegrasikan model kepercayaan (trust) dengan berpendapat bahwa kepercayaan (trust) berhubungan dengan perceived usefulness dan perceived easy of use. Gefen (1997), Gefen (2000), Gefen dan Straub (2000), Gefen dan Straub (2002) juga mengintegrasikan trust, perceived usefulness dan perceived easy of use dalam konteks e-servis. Ada dukungan teoritis dan empiris untuk mengintegrasikan trust dengan variabel TAM. Trust adalah salah satu penentu perceived usefulness (manfaat yang dirasakan), terutama dalam lingkungan on-line, karena bagian dari jaminan bahwa konsumen akan mendapatkan manfaat yang diharapkan dari tampilan website (Gefen, 1997). Chircu, et al., (2000), mengemukakan bahwa kepercayaan secara positif mempengaruhi perceived usefulness karena memungkinkan konsumen menjadi rentan terhadap website peritail. Di sisi lain, jika website peritail tidak layak mendapatkan kepercayaan, konsumen dapat menderita kerugian dari transaksi tersebut saat peritail berperilaku oportunistik.

Chircu, et al., (2000), berpendapat bahwa trust pada e-commerce meningkat kemudahan penggunaan perceived easy of use. Logika yang mendasari mereka adalah bahwa trust mengurangi kebutuhan konsumen untuk memahami,

Budiyanto \& Dewi Pangestuning Utami; Integrasi Trust dan Technology Acceptance Model (TAM) dalam Intention to Transact 


\section{SEGMEN Jurnal Manajemen dan Bisnis \\ Volume 17 No 2 Juli 2021 \\ p-ISSN: 0216-938X e-ISSN: 2684-8414}

memonitor, dan mengontrol situasi, memfasilitasi transaksi dan membuatnya mudah. Dalam konteks e-commerce kepercayaan (trust) akan mengurangi kebutuhan konsumen untuk memantau tindakan tampilan website dan memeriksa setiap detail, membuat transaksi online lebih mudah. Di samping itu, ketika kepercayaan rendah, konsumen akan terpaksa memberikan perhatian khusus kepada semua aspek proses transaksi, meningkatkan waktu dan tenaga yang dibutuhkan. Berdasarkan penjelasan tersebut peneliti mengajukan hipotesis sebagai berikut:

$\mathrm{H}_{1}$ : Trust berpengaruh secara positif terhadap Perceived Uusefulness

$\mathrm{H}_{2}$ : Trust berpengaruh secara positif terhadap Perceived Ease of Use

b. Hubungan Trust terhadap Perceived Risk

Trust pada dasarnya dibutuhkan hanya dalam hal-hal yang tidak pasti, karena itu berarti secara efektif menanggung risiko dan menjadi rentan terhadap pihak yang terpercaya, (Hosmer, 1995). Kepercayaan konsumen dapat digambarkan sebagai fungsi dari tingkat risiko yang terlibat didalam situasi (Kucuk dan Arslan, 2000). Kepercayaan sangat penting dalam transaksi ekonomi karena mengurangi risiko menjadi korban perilaku oportunistik (Williamson, 1985). Ini berlaku terhadap perilaku konsumen on-line, di mana transaksi tunduk pada oportunisme penjual. Kepercayaan juga telah terbukti mengurangi risiko keberadaan dimanfaatkan oleh penjual didalam chanel (Geyskens, 1998) dan telah terjadi terkait dengan pengurangan risiko yang dirasakan dalam perubahan organisasi (Doney dan Cannon, 1997).
Trust pada e-commerce mengurangi perilaku tidak pasti dan risiko terkait yang terkait dengan kemungkinan bahwa web retailer berperilaku secara oportunistik. Ketika orang mempercayai orang lain, mereka berasumsi bahwa orang yang mereka percayai akan berperilaku seperti yang diharapkan, mengurangi kompleksitas interaksi. Konsumen cenderung berasumsi bahwa web retailer tepercaya tidak akan terlibat dalam perilaku oportunistik (Gefen,2000). Jadi trust mengurangi risiko yang dirasakan (Mayer, et al, 1995). Oleh karena itu, kepercayaan mengurangi risiko yang terlibat dalam bertransaksi dengan web retailer. Jadi, kepercayaan pada web retailer mengurangi keyakinan risiko tentang transaksi online dengannya pengecer. Berdasarkan penjelasan tersebut peneliti mengajukan hipotesis sebagai berikut:

$\mathrm{H}_{3}$ : Trust berpengaruh secara positif terhadap Perceived Risk

c. Hubungan Trust terhadap Intention to Transact

Trust adalah ciri khas dari sebagian besar interaksi ekonomi dan sosial yang tidak pasti. Semua interaksi membutuhkan elemen trust, terutama yang dilakukan di lingkungan ecommerce yang tidak pasti (Ba dan Pavlou, 2002; Lee, 1998). Trust telah lama dianggap sebagai katalisator dalam hubungan antara konsumen dan pemasar karena mampu memberikan ekspektasi transaksi yang berhasil. Trust selalu menjadi elemen penting dalam mempengaruhi perilaku konsumen dan telah terbukti memiliki tingkat signifikansi dalam lingkungan yang tidak

Budiyanto \& Dewi Pangestuning Utami; Integrasi Trust dan Technology Acceptance Model (TAM) dalam Intention to Transact 


\section{SEGMEN Jurnal Manajemen dan Bisnis \\ Volume 17 No 2 Juli 2021 \\ p-ISSN: 0216-938X e-ISSN: 2684-8414}

pasti, seperti itu sebagai konteks $e$ commerce (Gefen dan Straub, 2002; Jarvenpaa dan Tractinsky, 1999; Moon dan Kim, 2002). Kurangnya kepercayaan menjadi salah satu alasan utama konsumen tidak terlibat dalam ecommerce (Keen, 1999). Dengan demikian orang mungkin berpendapat bahwa pentingnya trust telah meningkat dalam e-commerce karena tingkat ketidakpastian yang tinggi di sebagian besar transaksi on-line (Fung dan Lee, 1999). Keen (1999), berpendapat bahwa trust adalah dasar dari $e$-commerce, dengan fokus pada implikasi strategis dari kepercayaan untuk hubungan konsumen dan pemasar.

Hoffman et al., (1999) berpendapat bahwa kurangnya trust menghalangi konsumen untuk terlibat dalam transaksi online karena mereka tidak mungkin bertransaksi dengan web retailer yang gagal menyampaikan rasa kepercayaannya, terutama karena ketakutan akan oportunisme dan kekhawatiran tentang pemanfaatan infrastruktur intemet. Secara umum, hubungan yang diusulkan antara trust dan attitude dibenarkan oleh menempatkan trust dalam konteks TRA sebagai keyakinan perilaku (Sheppard, 1988). Trust menciptakan sikap positif dan kontrol perilaku yang dirasakan terhadap transaksi dengan web retailer, mengurangi ketidakpastian dan memberikan harapan transaksi yang memuaskan, sehingga berpengaruh positif terhadap perilaku konsumen niat untuk bertransaksi. Berdasarkan penjelasan tersebut peneliti mengajukan hipotesis sebagai berikut:
$\mathrm{H}_{4}$ : Trust berpengaruh secara positif terhadap Intention to Transact.

d. Hubungan Perceived Usefulness terhadap Intention to Transact

Menurut Pavlou (2003), hampir setiap langkah dalam proses transaksi online mengharuskan konsumen untuk berinteraksi dengan website dan menggunakan teknologi internet. Menurut Pavlou (2002) perceived usefulness didefinisikan sebagai sejauh mana konsumen percaya bahwa berhubungan dengan teknologi tertentu akan memfasilitasi proses transaksi. Penerapan konsep perceived usefulness konsumen berpersepsi dengan adanya perdagangan e-commerce dapat mempermudah dalam proses pembelian orang-orang yang mudah menggunakannya, berguna, dan menyenangkan dapat meningkatkan berbelanja online (Rizwan, et al., 2014).

Penelitian yang dilakukan oleh Sutomo, Devi (2012), Istighafardani dan Setyorini (2017), Indahwati, Fenny (2012), membuktikan bahwa perceived usefulness berpengaruh positif dan signifikan terhadap intention to transact. Berdasarkan penjelasan tersebut peneliti mengajukan hipotesis sebagai berikut:

$\mathrm{H}_{5}$ : Perceived usefulness berpengaruh positif terhadap Intention to Transact

e. Perceived Ease of Use terhadap Intention to Transact

Menurut Wen, et al., (2011), perceived ease of use didefinisikan sebagai sejauh mana konsumen merasakan kemudahan interaksi dengan situs website dan dapat menerima informasi yang dibutuhkan. Perceived

Budiyanto \& Dewi Pangestuning Utami; Integrasi Trust dan Technology Acceptance Model (TAM) dalam Intention to Transact 


\section{SEGMEN Jurnal Manajemen dan Bisnis \\ Volume 17 No 2 Juli 2021 \\ p-ISSN: 0216-938X e-ISSN: 2684-8414}

ease of use mengindikasikan bahwa toko online mampu memenuhi kebutuhan konsumen akan kemudahan untuk pencarian informasi maupun kemudahan bertransaksi. Sedangkan menurut Pavlou (2002) perceived ease of use didefinisikan sebagai sejauh mana konsumen percaya berhubungan dengan teknologi tertentu akan bebas dari usaha. Diterapkan pada perilaku konsumen online, berhubungan dengan website dianggap dapat memfasilitasi proses transaksi karena mudah dioperasikan dan cenderung memicu niat transaksi konsumen.

Penelitian yang dilakukan oleh Sutomo, Devi (2012), Istighafardani dan Setyorini (2017), Indahwati, Fenny (2012), membuktikan bahwa perceived usefilness berpengaruh positif dan signifikan terhadap intention to transact. Berdasarkan penjelasan tersebut peneliti mengajukan hipotesis sebagai berikut:

$\mathrm{H}_{6}$ : Perceived Ease of Use berpengaruh positif terhadap Intention to Transact

f. Hubungan Perceived Risk terhadap Intention to Transact

Menurut Featherman and Pavlou (2003), mendefinisikan risiko yang dirasakan sebagai potensi kerugian dalam mengejar hasil yang diinginkan dalam menggunakan layanan elektronik. ketika terlibat dalam transaksi online, konsumen berhak khawatir tentang berbagai jenis risiko yang ada. Risiko yang dirasakan menggambarkan ekspektasi konsumen mengenai penjual untuk terlibat dalam perilaku selama bertransaksi (Pavlou, 2002). Faktanya, menurut (Jarvenpaa, et al., 2000 dalam Pavlou, 2002) menyatakan bahwa pengurangan risiko yang terkait dengan pembelian dari toko internet kemungkinan akan meningkatkan kemungkinan pembelian oleh konsumen dari toko itu yang secara tidak langsung mempengaruhi niat untuk bertransaksi. Semakin banyak informasi yang diperoleh konsumen mengenai produk dan golongan produk, semakin dapat diramalkan konsekuensi yang mungkin timbul, dan dengan demikian semakin rendah risiko yang dirasakan (Schiffman dan Kanuk, 2008:172).

Penelitian yang dilakukan oleh Sutomo, Devi (2012), Indahwati, Fenny (2012), Aribowo dan Nugroho (2013) membuktikan bahwa perceived risk berpengaruh negatif dan signifikan terhadap intention to transact. Berdasarkan penjelasan tersebut peneliti mengajukan hipotesis sebagai berikut:

$\mathrm{H}_{7}$ : Perceived Risk berpengaruh negatif terhadap Intention to Transact.

\section{METODE PENELITIAN}

Penelitian ini termasuk penelitian kausal (Sekaran \& Bougie, 2013), yang menggambarkan satu atau lebih faktor yang menyebabkan masalah, yaitu: trust, perceived usefulness, perceived ease of use, perceived risk, digambarkan menyebabkan intention to transact pada Tokopedia. Secara terinci definisi variabelnya sebagai berikut:

a. Intention to Transact

Menurut Pavlou (2002) intention to transact didefinisikan sebagai niat konsumen untuk terlibat dalam elektronik yaitu pertukaran hubungan dengan pengecer website, seperti berbagi informasi bisnis, memelihara hubungan bisnis, dan melakukan transaksi bisnis. Penerapan $e$ -

Budiyanto \& Dewi Pangestuning Utami; Integrasi Trust dan Technology Acceptance Model (TAM) dalam Intention to Transact 


\section{SEGMEN Jurnal Manajemen dan Bisnis \\ Volume 17 No 2 Juli 2021 \\ p-ISSN: 0216-938X e-ISSN: 2684-8414}

commerce mengharuskan konsumen menggunakan situs website untuk menerima dan memberikan informasi dan menyelesaikan pembelian produk. Indikator untuk mengukur intention to transact mengacu pada pendapat (Pavlou, 2003) yaitu:

1.Berniat untuk menggunakan website

2.Menggunakan website dikemudian hari

3.Akan segera bertransaksi
menggunakan website

\section{b. Trust}

Trust adalah ciri khas dari sebagian besar interaksi ekonomi dan sosial yang tidak pasti. Semua interaksi membutuhkan elemen trust, terutama yang dilakukan di lingkungan e-commerce yang tidak pasti (Ba dan Pavlou, 2002; Lee, 1998). Trust telah lama dianggap sebagai katalisator dalam hubungan antara konsumen dan pemasar karena mampu memberikan ekspektasi transaksi yang berhasil. Trust selalu menjadi elemen penting dalam mempengaruhi perilaku konsumen dan telah terbukti memiliki tingkat signifikansi dalam lingkungan yang tidak pasti, seperti itu sebagai konteks e-commerce (Gefen dan Straub, 2002; Jarvenpaa dan Tractinsky, 1999; Moon dan Kim, 2002). Indikator untuk mengukur trust mengacu pada pendapat (Povlou, 2003) yaitu:

1. Trustworthy

2. Pramises and commitments

3. Best interests in mind

c. Perceived Usefulness

Menurut Pavlou (2002) perceived usefulness didefinisikan sebagai sejauh mana konsumen percaya bahwa berhubungan dengan teknologi tertentu akan memfasilitasi proses transaksi. Indikator untuk mengukur perceived usefulness mengacu pada pendapat (Lui and Jamieson, 2003) yaitu:

\section{Performance}

2. Productivity

3. Effectiveness

4. Useful

d. Perceived ease of use

Menurut Pavlou (2002) perceived ease of use didefinisikan sebagai sejauh mana konsumen percaya berhubungan dengan teknologi tertentu akan bebas dari usaha. Indikator untuk mengukur perceived ease of use mengacu pada pendapat (Pavlou, 2003) yaitu:

\section{Understandable \\ 2. Ease to use \\ 3. Ease to information}

\section{e. Perceived risk}

Menurut Pavlou (2002) perceived risk didefinisikan sebagai harapan subyektif konsumen untuk mendapatkan kerugian dalam mengejar hasil yang diinginkan. Risiko yang dirasakan menggambarkan ekspektasi konsumen mengenai penjual untuk terlibat dalam perilaku selama bertransaksi. Indikator untuk mengukur perceived risk mengacu pada pendapat (Lui and Jamieson, 2003) yaitu:

1. Khawatir mengalami kerugian saat bertransaksi

2. Mempertimbangkan risiko yang mungkin terjadi

3. Menimbulkan masalah saat bertransaksi

Populasi dalam penelitian ini adalah seluruh konsumen pengguna marketplace tokopedia. Teknik sampling yang digunakan dalam penelitian ini nonprobability sampling dengan teknik purposive sampling. Dalam desain nonprobability sampling, elemen-elemen yang terdapat dalam populasi tidak mempunyai probabilitas yang

Budiyanto \& Dewi Pangestuning Utami; Integrasi Trust dan Technology Acceptance Model (TAM) dalam Intention to Transact 


\section{SEGMEN Jurnal Manajemen dan Bisnis \\ Volume 17 No 2 Juli 2021 \\ p-ISSN: 0216-938X e-ISSN: 2684-8414}

sama untuk dipilih sebagai subjek sampel. Purposive sampling adalah teknik penentuan sampel dengan kriteria yang ditetapkan oleh peneliti (Sekaran dan Bougie, 2016:248). Adapun kriteria konsumen yang dapat dijadikan responden adalah sebagai berikut:

a. Masyarakat yang menggunakan aplikasi tokopedia.

b. Masyarakat yang berdomisili di Kabupaten Purworejo.

c. Konsumen yang berusia minimal 17 tahun.

\section{HASIL PENELITIAN DAN \\ PEMBAHASAN}

\section{Pengujian instrumen}

Uji validitas ini dilakukan dengan rumus Korelasi Pearson (Correlation Product Moment). Apabila korelasi faktor positif besarnya $\geq 0,3$. Uji reliabilitas ini diukur dengan menggunakan Cronbach Alpha. Jika nilai a (Alpha Cronbach) > 0,7 maka item variabel tersebut dinyatakan reliabel

\section{TAM}

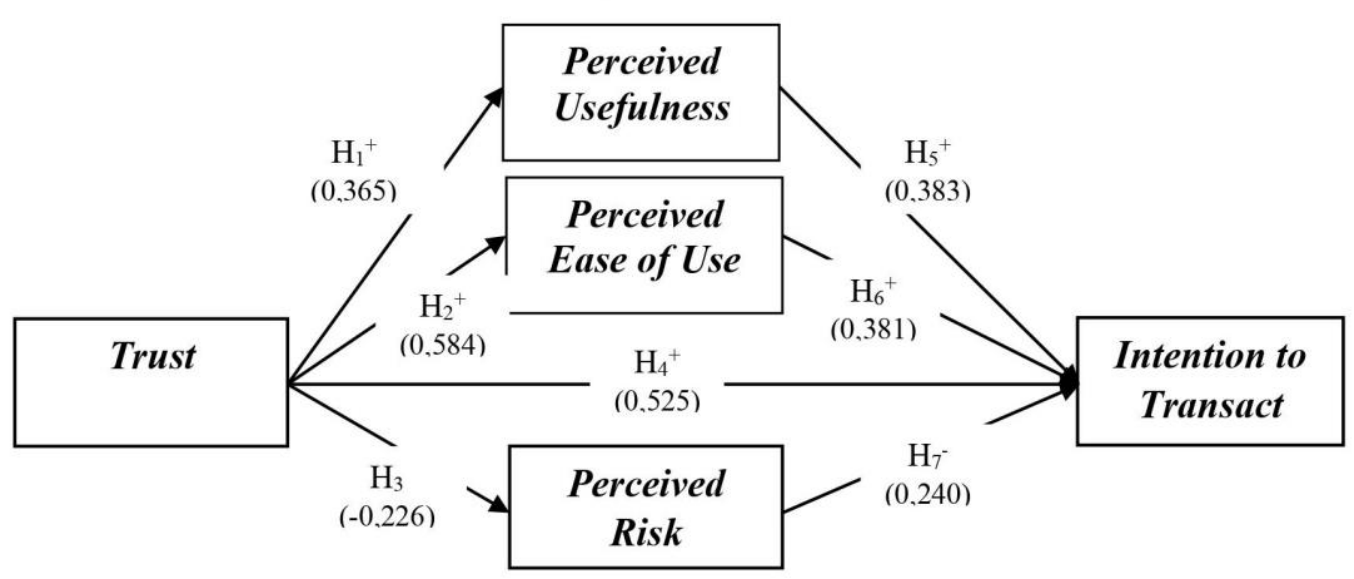

Gambar 2.

\section{Hasil Analisis Data}

\section{HASIL PENGUJIAN HIPOTESIS}

1. Pengaruh Trust terhadap TAM (Perceived Usefulness, Perceived Easy of Use).

Langkah 1 bertujuan untuk membuktikan hipotesis pertama $\left(\mathrm{H}_{1}\right)$, yaitu trust berpengaruh positif terhadap perceived usefulness.

Berdasarkan hasil analisis regresi pengaruh trust terhadap perceived usefulness menghasilkan nilai koefisien regresi $(\beta)$ sebesar 0,365 dengan nilai signifikansi 0,000 (p-value < 0,05).
Sehingga diperoleh persamaan garis regresi $Y=0,365 X$. Hal ini menunjukkan bahwa hipotesis pertama yang diajukan dalam penelitian ini diterima.

Diterimanya hipotesis pertama dalam penelitian ini dikarenakan aplikasi tokopedia sangat dipercaya dapat memenuhi janji dan komitmennya dimana dapat memenuhi kepentingan konsumen sehingga meningkatkan perilaku pembelian konsumen dan frekuensi pembelian seperti menampilkan desain menarik yang dapat

Budiyanto \& Dewi Pangestuning Utami; Integrasi Trust dan Technology Acceptance Model (TAM) dalam Intention to Transact 


\section{SEGMEN Jurnal Manajemen dan Bisnis \\ Volume 17 No 2 Juli 2021 \\ p-ISSN: 0216-938X e-ISSN: 2684-8414}

menimbulkan kecenderungan konsumen betah berlama-lama menggunakan aplikasi tokopedia sehingga konsumen mendapatkan manfaat dari aplikasi tokopedia yang dapat dipercaya konsumen.

Hasil penelitian ini sejalan dengan gagasan Gefen (1997) yang menyatakan trust adalah salah satu penentu perceived usefulness (manfaat yang dirasakan), terutama dalam lingkungan online, karena bagian dari jaminan bahwa konsumen akan mendapatkan manfaat yang diharapkan dari tampilan website. Chircu, et al., (2000) juga mengemukakan bahwa kepercayaan secara positif mempengaruhi perceived usefulness karena memungkinkan konsumen menjadi rentan terhadap website peritail.

Terbuktinya hipotesis pertama dalam penelitian ini menguatkan hasil penelitian sebelumnya yang dilakukan Pavlou (2003), Chircu, Davis, dan Kauffman (2000), Gefen (1997), Gefen (2000), Gefen dan Straub (2000), dan Gefen dan Straub (2002) yang menyatakan bahwa trust berpengaruh positif dan signifikan terhadap perceived usefulness.

Langkah 2 bertujuan untuk membuktikan hipotesis kedua $\left(\mathrm{H}_{2}\right)$, yaitu trust berpengaruh positif terhadap perceived ease of use.

Berdasarkan hasil analisis regresi pengaruh trust terhadap perceived ease of use menghasilkan nilai koefisien regresi $(\beta)$ sebesar 0,584 dengan nilai signifikansi 0,000 (p-value $<0,05)$. Sehingga diperoleh persamaan garis regresi $Y=0,584 X$. Hal ini menunjukkan bahwa hipotesis kedua yang diajukan dalam penelitian ini diterima.

Diterimanya hipotesis kedua dalam penelitian ini karena aplikasi tokopedia sangat dipercaya memberikan langkahlangkah penggunaan yang jelas dan mudah dipahami seperti bagaimana cara melakukan pembelian, pembayaran maupun cara mengambil voucher dan langkah yang lainnya. Hal ini dilakukan oleh pengelola tokopedia untuk menepati janji dan komitmennya terhadap pengguna aplikasi tokopedia agar konsumen lebih mudah dalam menggunakan aplikasi tokopedia. Kepercayaan konsumen terhadap tokopedia mengurangi kebutuhan konsumen untuk memantau tampilan website dan memeriksa setiap detailnya, dan membuat transaksi online lebih mudah dilakukan. Oleh karena itu konsumen sangat percaya dengan adanya kemudahan penggunaan pada aplikasi tokopedia.

Hasil penelitian ini sejalan dengan gagasan Chircu, et al., (2000), bahwa trust pada e-commerce meningkat kemudahan penggunaan perceived easy of use. Logika yang mendasari mereka adalah bahwa trust mengurangi kebutuhan konsumen untuk memahami, memonitor, dan mengontrol situasi, memfasilitasi transaksi dan membuatnya mudah. Dalam konteks e-commerce kepercayaan (trust) akan mengurangi kebutuhan konsumen untuk memantau tindakan tampilan website dan memeriksa setiap detail, membuat transaksi online lebih mudah.

Terbuktinya hipotesis kedua dalam penelitian ini menguatkan hasil

Budiyanto \& Dewi Pangestuning Utami; Integrasi Trust dan Technology Acceptance Model (TAM) dalam Intention to Transact 


\section{SEGMEN Jurnal Manajemen dan Bisnis \\ Volume 17 No 2 Juli 2021 \\ p-ISSN: 0216-938X e-ISSN: 2684-8414}

penelitian sebelumnya yang dilakukan Pavlou (2003), Chircu (2000), dan Ring dan Van de Ven (1994) yang menyatakan bahwa trust berpengaruh positif dan signifikan terhadap perceived ease of use.

\section{Pengaruh Trust terhadap Perceived Risk}

Langkah 3 bertujuan untuk membuktikan hipotesis ketiga $\left(\mathrm{H}_{3}\right)$, yaitu trust berpengaruh positif terhadap perceived risk.

Berdasarkan hasil analisis regresi pengaruh trust terhadap perceived risk menghasilkan nilai koefisien regresi $(\beta)$ sebesar $-0,226$ dengan nilai signifikansi 0,013 (p-value $<0,05$ ). Sehingga diperoleh persamaan garis regresi $\mathrm{Y}=$ 0,226X. Hal ini menunjukkan bahwa hipotesis ketiga dimana diduga terdapat hubungan negatif dari trust terhadap perceived risk ditolak.

Hal ini tidak konsisten seperti hasil penelitian yang dilakukan Pavlou (2003) yang menyatakan bahwa trust berpengaruh positif terhadap perceived risk. Namun hasil temuan ini sejalan dengan penelitian yang dilakukan oleh Kim, et al., (2003) dimana jika tingkat kepercayaan pada konsumen melebihi risiko yang dirasakan maka konsumen akan terlibat dalam hubungan yang berisiko. Dengan kata lain kepercayaan adalah penentu utama dari tindakan dalam situasi dimana terdapat risiko yang dianggap sebagai hasil negatif.

Kepercayaan yang tinggi terhadap aplikasi tokopedia membuat konsumen tidak terlalu khawatir dengan risiko. Aplikasi tokopedia memberikan jaminan terkait dengan transaksi yang sedang dilakukan antara konsumen dengan penjual. Adapun jaminan-jaminan yang diberikan aplikasi tokopedia yaitu jaminan pasti ready yaitu jaminan ketersediaan barang, pasti ori yaitu jaminan keaslian barang yang diberikan pada konsumen, garansi 7 hari yaitu jaminan pengembalian barang jika barang rusak atau tidak sesuai deskripsi atau pesanan. Dengan adanya hal tersebut tingkat kepercayaan konsumen akan meningkat dan tidak resiko yang dirasakan konsumen rendah.

\section{Pengaruh Trust terhadap Intention to} Transact

Langkah 4 bertujuan untuk membuktikan hipotesis keempat $\left(\mathrm{H}_{4}\right)$, yaitu trust berpengaruh positif terhadap intention to transact.

Berdasarkan hasil analisis regresi pengaruh trust terhadap intention to transact menghasilkan nilai koefisien regresi $(\beta)$ sebesar 0,525 dengan nilai signifikansi 0,000 ( $p$-value $<0,05)$. Sehingga diperoleh persamaan garis regresi $\mathrm{Y}=0,525 \mathrm{X}$. Hal ini menunjukkan bahwa hipotesis keempat yang diajukan dalam penelitian ini diterima.

Diterimanya hipotesis keempat dalam penelitian ini karena saat konsumen membeli produk pada aplikasi tokopedia selalu sesuai dengan foto pada laman toko, dengan begitu konsumen sangat percaya berbelanja pada aplikasi tokopedia dan dapat meningkatkan niat konsumen untuk bertransaksi. Tidak hanya itu, aplikasi tokopedia selalu memenuhi janji dan komitmennya salah satunya adalah layanan yang diberikan 


\section{SEGMEN Jurnal Manajemen dan Bisnis \\ Volume 17 No 2 Juli 2021 \\ p-ISSN: 0216-938X e-ISSN: 2684-8414}

pada konsumen selalu memuaskan dengan begitu dapat meningkatkan kepercayaan konsumen untuk bertransaksi. Aplikasi tokopedia juga selalu memnuhi kepentingan konsumen dimana produk yang dijual pada aplikasi tokopedia tidak hanya barang-barang konsumtif saja tetapi menyediakan produk digital yang membuat konsumen percaya untuk bertransaksi pada aplikasi tokopedia.

Hasil penelitian ini sejalan dengan gagasan Gefen dan Straub (2002), Jarvenpaa dan Tractinsky (1999), Moon dan Kim (2002). Dimana trust telah lama dianggap sebagai katalisator dalam hubungan antara konsumen dan pemasar karena mampu memberikan ekspektasi transaksi yang berhasil. Trust menciptakan sikap positif dan kontrol perilaku yang dirasakan terhadap transaksi dengan web retailer, mengurangi ketidakpastian dan memberikan harapan transaksi yang memuaskan, sehingga berpengaruh positif terhadap perilaku konsumen niat untuk bertransaksi.

Terbuktinya hipotesis keempat dalam penelitian ini menguatkan hasil penelitian sebelumnya yang dilakukan Pavlou (2003), Gefen dan Straub (2002), Jarvenpaa dan Tractinsky (1999), dan Moon dan Kim (2002) yang menyatakan bahwa trust berpengaruh positif dan signifikan terhadap intention to transact.

\section{Pengaruh Perceived Usefulness terhadap Intention to Transact}

Langkah 5 bertujuan untuk membuktikan hipotesis kelima $\left(\mathrm{H}_{5}\right)$, yaitu perceived usefulness berpengaruh positif terhadap intention to transact.

Berdasarkan hasil analisis regresi pengaruh perceived usefulness terhadap intention to transact menghasilkan nilai koefisien regresi $(\beta)$ sebesar 0,383 dengan nilai signifikansi 0,000 ( $p$-value $<0,05)$. Sehingga diperoleh persamaan garis regresi $\mathrm{Y}=0,383 \mathrm{X}$. Hal ini menunjukkan bahwa hipotesis kelima yang diajukan dalam penelitian ini diterima.

Diterimanya hipotesis kelima dalam penelitian ini dikarenakan adanya aplikasi tokopedia dapat meningkatkan perilaku pembelian dimana aplikasi tokopedia sering memberikan potongan harga yang dapat mempengaruhi sikap konsumen dalam belanja online karena terdapat manfaat untuk lebih hemat dalam berbelanja. Aplikasi tokopedia dapat menimbulkan peningkatan frekuensi belanja konsumen, karena aplikasi tokopedia menyediakan berbagai penampilan dengan desain menarik yang dapat menimbulkan kecenderungan konsumen betah berlama-lama menggunakan aplikasi tokopedia. Hal ini dapat meningkatkan frekuensi pembelian yang dilakukan oleh konsumen. Aplikasi tokopedia juga tidak hanya menyediakan produk barang elektronik, peralatan kantor dan rumah tangga, peralatan olahraga, kosmetik, perlengkapan bayi, fashion tetapi menyediakan berbagai produk digital seperti listrik PLN, pulsa, tagihan, pajak, Top-Up, travel and entertainment, investasi, asuransi, pinjaman, donasi, dan masih banyak lagi. Hal tersebut membuat konsumen merasa adanya 


\section{SEGMEN Jurnal Manajemen dan Bisnis \\ Volume 17 No 2 Juli 2021 \\ p-ISSN: 0216-938X e-ISSN: 2684-8414}

manfaat yang dirasakan dengan menggunakan aplikasi tokopedia. Dengan begitu, aplikasi tokopedia dapat meningkatkan niat konsumen untuk bertransaksi.

Hasil penelitian ini sejalan dengan gagasan Pavlou (2002) yang menyatakan bahwa perceived usefulness merupakan sejauh mana konsumen percaya bahwa berhubungan dengan teknologi tertentu akan memfasilitasi proses transaksi. Sejalan dengan Pavlou (2002), menurut Menurut Kim, et al., (2007) dalam penelitiannya menyatakan bahwa mereka melakukan pembelian disitus web karena adanya perceived usefulness (misalnya, kenyamanan meningkat, penghematan biaya, penghematan waktu, peningkatan berbagai produk untuk memilih dibandingkan dengan belanja secara tradisional).

Terbuktinya hipotesis kelima dalam penelitian ini menguatkan hasil penelitian sebelumnya yang dilakukan Pavlou (2003), Lui and Jamieson (2003), Sutomo (2012), Istighafardani dan Setyorini (2017), Indahwati (2012), yang menyatakan bahwa perceived usefulness berpengaruh positif dan signifikan terhadap intention to transact.

5. Pengaruh Perceived Ease of Use terhadap Intention to Transact

Langkah 6 bertujuan untuk membuktikan hipotesis keenam $\left(\mathrm{H}_{6}\right)$, yaitu perceived ease of use berpengaruh positif terhadap intention to transact.

Berdasarkan hasil analisis regresi pengaruh perceived ease of use terhadap intention to transact menghasilkan nilai koefisien regresi $(\beta)$ sebesar 0,381 dengan nilai signifikansi 0,000 ( $p$-value $<0,05)$. Sehingga diperoleh persamaan garis regresi $\mathrm{Y}=0,381 \mathrm{X}$. Hal ini menunjukkan bahwa hipotesis keenam yang diajukan dalam penelitian ini diterima.

Diterimanya hipotesis keenam dalam penelitian ini dikarenakan aplikasi tokopedia menggunakan bahasa yang mudah dimengerti dan baku. Selain itu, penggunaan warna serta penempatan ikon-ikon yang ada dalam aplikasi mudah untuk dimengerti berbagai kalangan konsumen. Aplikasi Tokopedia tentu sangat memudahkan konsumen yang tidak mempunyai waktu luang untuk berbelanja di toko tradisional. Penggunaan aplikasi tokopedia tersedia dalam berbagai mode penggunaan, yaitu dengan akses melalui website dan menggunakan aplikasi yang dapat diunduh dalam playstore smartphone. Hal tersebut memudahkan pengguna mengakses tokopedia dengan berbagai cara. Aplikasi tokopedia juga dilengkapi dengan fitur search engine yang memudahkan konsumen dalam pencarian informasi seperti informasi toko. Dengan begitu aplikasi tokopedia dapat meningkatkan niat konsumen untuk bertransaksi.

Hasil penelitian ini sejalan dengan gagasan Wen, et al., (2011) yang menyatakan Perceived ease of use mengindikasikan toko online mampu memenuhi kebutuhan konsumen akan kemudahan untuk pencarian informasi maupun kemudahan bertransaksi. Diterapkan pada perilaku konsumen online, berhubungan dengan website dianggap dapat memfasilitasi proses 


\section{SEGMEN Jurnal Manajemen dan Bisnis \\ Volume 17 No 2 Juli 2021 \\ p-ISSN: 0216-938X e-ISSN: 2684-8414}

transaksi karena mudah dioperasikan dan cenderung memicu niat transaksi konsumen (Pavlou, 2002).

Terbuktinya hipotesis keenam dalam penelitian ini menguatkan hasil penelitian sebelumnya yang dilakukan Pavlou (2003), Lui and Jamieson (2003), Sutomo (2012), Istighafardani dan Setyorini (2017), Indahwati (2012), yang menyatakan bahwa perceived ease of use berpengaruh positif dan signifikan terhadap intention to transact.

\section{Pengaruh Perceived Risk terhadap Intention to Transact}

Langkah 7 bertujuan untuk membuktikan hipotesis ketujuh $\left(\mathrm{H}_{7}\right)$, yaitu perceived risk berpengaruh positif terhadap intention to transact.

Berdasarkan hasil analisis regresi pengaruh perceived risk terhadap intention to transact menghasilkan nilai koefisien regresi $(\beta)$ sebesar $-0,240$ dengan nilai signifikansi 0,008 ( $p$-value < $0,05)$. Sehingga diperoleh persamaan garis regresi $Y=-0,240 \mathrm{X}$. Hal ini menunjukkan bahwa hipotesis keenam yang diajukan dalam penelitian ini diterima.

Diterimanya hipotesis ketujuh dalam penelitian ini dikarenakan sebelum melakukan transaksi, konsumen akan mencari banyak informasi mengenai toko dan produk yang akan dibeli, semakin banyak informasi yang dikumpulkan maka konsumen tidak khawatir mengalami kerugian ketika bertransaksi pada aplikasi tokopedia. Aplikasi tokopedia mudah dipahami oleh konsumen sehingga akan meminimalisir kesalahan dan masalah yang akan timbul.
Pengelola tokopedia memberikan pelayanan yang optimal mengenai risiko yang kemungkinan didapatkan oleh konsumen. Pemberian edukasi kepada konsumen melalui informasi mengenai produk, penjual, teknologi yang digunakan serta review konsumen, yang diberikan oleh pengelola sangat membantu konsumen untuk memiliki pengetahuan mengenai konsekuensi suatu pembelian. hal ini dilakukan untuk meminimalisir masalah yang ditimbulkan dalam bertransaksi. Dengan demikian, semakin rendah risiko yang mungkin terjadi akan meningkatkan niat konsumen untuk bertransaksi.

Hasil penelitian ini sejalan dengan gagasan Jarvenpaa, et al., (2000) dalam Pavlou (2002) menyatakan bahwa pengurangan risiko yang terkait dengan pembelian dari toko internet kemungkinan akan meningkatkan kemungkinan pembelian oleh konsumen dari toko itu yang secara tidak langsung mempengaruhi niat untuk bertransaksi. Semakin banyak informasi yang diperoleh konsumen mengenai produk dan golongan produk, semakin dapat diramalkan konsekuensi yang mungkin timbul, dan dengan demikian semakin rendah risiko yang dirasakan (Schiffman dan Kanuk, 2008:172).

Terbuktinya hipotesis ketujuh dalam penelitian ini menguatkan hasil penelitian sebelumnya yang dilakukan Pavlou (2003), Lui and Jamieson (2003), Sutomo (2012), Indahwati (2012), Aribowo dan Nugroho (2013) yang menyatakan bahwa perceived risk berpengaruh negatif dan signifikan terhadap intention to transact. 


\section{SEGMEN Jurnal Manajemen dan Bisnis \\ Volume 17 No 2 Juli 2021 \\ p-ISSN: 0216-938X e-ISSN: 2684-8414}

\section{KESIMPULAN}

Berdasarkan hasil analisis integrasi trust dan technology acceptance model (tam) dalam intention to transact (studi pada konsumen pengguna tokopedia) maka dapat diambil kesimpulan bahwa trust terhadap perceived usefulness positif dan signifikan artinya tokopedia sangat dipercaya dapat memenuhi janji dan komitmennya dimana dapat memenuhi kepentingan konsumen sehingga meningkatkan perilaku pembelian konsumen dan frekuensi pembelian. trust berpengaruh positif dan signifikan terhadap perceived ease of use yang artinya tokopedia sangat dipercaya memberikan langkahlangkah penggunaan yang jelas dan mudah dipahami seperti bagaimana cara melakukan pembelian, pembayaran maupun cara mengambil voucher dan langkah yang lainnya. trust berpengaruh negatif dan signifikan terhadap perceived risk artinya jika tingkat kepercayaan pada konsumen melebihi risiko yang dirasakan maka konsumen akan terlibat dalam hubungan yang berisiko. Dengan kata lain kepercayaan adalah penentu utama dari tindakan dalam situasi dimana terdapat risiko yang dianggap sebagai hasil negatif. trust berpengaruh positif dan signifikan terhadap intention to transact yang artinya konsumen membeli produk pada aplikasi tokopedia selalu sesuai dengan foto pada laman toko, dengan begitu konsumen sangat percaya berbelanja pada aplikasi tokopedia dan dapat meningkatkan niat konsumen untuk bertransaksi. Perceived usefulness berpengaruh positif dan signifikan terhadap intention to transact yang artinya tokopedia sering memberikan potongan harga yang dapat mempengaruhi sikap konsumen dalam belanja online karena terdapat manfaat untuk lebih hemat dalam berbelanja. Perceived ease of use berpengaruh positif dan signifikan terhadap intention to transact artinya tokopedia menggunakan bahasa yang mudah dimengerti dan baku. Selain itu, penggunaan warna serta penempatan ikon-ikon yang ada dalam aplikasi mudah untuk dimengerti berbagai kalangan konsumen. Perceived risk berpengaruh negatif dan signifikan terhadap intention to transact yang artinya sebelum melakukan transaksi, konsumen akan mencari banyak informasi mengenai toko dan produk yang akan dibeli, semakin banyak informasi yang dikumpulkan maka konsumen tidak khawatir mengalami kerugian ketika bertransaksi pada aplikasi tokopedia.

\section{DAFTAR PUSTAKA}

Aribowo, Dwiputra.A., dan Nugroho, Mahendra.A. 2013. Pengaruh trust dan perceived risk terhadap niat untuk bertransaksi menggunakan ecommerce. Jurnal nominal. 2(1): 1135.

Ba, Sulin. 2001. Establishing Online Trust Trough and Community Responsibility System. Decision Support System. 323-336.

Bhatnagar, Amit., Misra, Sanjog., and Rao, H. Raghav. 2000. On Risk, Convenience, An Internet Shopping Behavior Communications of the ACM. 48(2): 98-105.

Belch, George. E., and Belch, Michael. A. 2003. Advertising and Promotion. An Integrated Marketing Communications Perspektive. The McGraw-Hill Companies.

Budiyanto \& Dewi Pangestuning Utami; Integrasi Trust dan Technology Acceptance Model (TAM) dalam Intention to Transact 


\section{SEGMEN Jurnal Manajemen dan Bisnis \\ Volume 17 No 2 Juli 2021 \\ p-ISSN: 0216-938X e-ISSN: 2684-8414}

Davis, Fred. D. 1986. A Technology Acceptence Model for Empirically Testing New End-User Information Systems Theory and Results. 1-291.

Davis, Fred. D. 1989. Perceived Usefulness, Perceived ease of use of Information Technology. Management Information Systems Reserch Center, Universitas of Minnesota MIS Quarterly. 13(3) : 319-340.

Davis, Fred. D., Bagozzi, Richard. P., and Warshaw, Paul. R. 1989. User Acceptance of Computer Technology: A Comparison of Two Theoretical Models. Manajement Science. 35(8) : 982-1002.

Featherman, Mauricio. S and Pavlou, Paul. A. 2003. Predicting E-Services Adoption: A Perceived Risk Facets Perspektive. International Journal of Human Computer Studies. 451-479.

Fishbein, Martin. and Ajzen, Icek. 1975. Belief, Attitude, Intention, and Behavior: An Introduction to Theory and Reaserch, Reading. MA: Addison-Wesley.

Ghozali, Imam. 2018. Aplikasi Multivariat dengan Program IBM SPSS 19. Semarang. Universitas Diponegoro.

Ghozali, Imam dan Ratmono, Dwi. 2017. Analisis Multavariat dan Ekonometrika. Semarang: Badan Penerbit Universitas Diponegoro.

Gurung, Anil. 2006. Emperical Investigation Of The Relationship Of Privacy, Security and Trust Behavioral Intention to Transact in E-Commerce. All Right reserved.

Hartono, Jogiyanto. 2013. Metodologi Penelitian Bisnis. Salah Kaprah dan
Pengalaman-pengalaman.

Edisi

Kelima. Yogyakarta: BPFE.

https://www.kompasiana.com/lifestule04

2/5e4f9b6a097f1bfb32/gaya-hidup

serba-instan-di-era-milenial

https://www.tribunnews.com/techno/2019/

11/26/ketahui-6-cara-aman-

berbelanja-dan-transaksi-online

https://www.pikiranrakyat.com/ekonomi/a

mp/pr-01318930/logistik-bagian-

gaya-hidup-era-digital

https://www.cnbcindonesia.com/tech/2019

1223152017-37-125264/e-

commerce-ri-tumbuh-pesat-tapi-

kalah-dari-china-singapura

https://www.suara.com/yoursay/2020/02/1

0/162614/pengaruh-e-commerce-

terhadap-pertumbuhan-

ekonomiindonesia

https://www.inews.id/finance/bisnis/10-e-

commerce-terpopuler-di-indonesia-

tokopedia-terdepan-shopee-geser-

bukalapak

https://m.merdeka.com/uang/survei-

terbaru-e-commerce-paling-

banyak-digunakan-masyarakat-

sepanjang-2019.html

https://www.tokopedia.com/

$\mathrm{Hu}$, Yong., Sun, Xin., Zhang, Jin., Xiangzhou, Zhang., Fanghao, Luo., and Huang, Lijun. 2009. A University Student Behavioral Intention Model of Online Shopping Based On TAM. International Conference on Information Management, Innovation Management and Industrial Engineering. 625-628.

Im, Il., Kim, Yongbeom., Han, Hyujoo.2007. The Effect Of Perceived Risk and Technology Type On Users' 


\section{SEGMEN Jurnal Manajemen dan Bisnis \\ Volume 17 No 2 Juli 2021 \\ p-ISSN: 0216-938X e-ISSN: 2684-8414}

Acceptance Of Technologies. Information \& Management. 1-9.

Indahwati, Fenny. 2012. Pengaruh dimensi propensity of trust, perceived risk, perceived usefulness, perceived ease of use terhadap intention to transact pada business to customer toko online.

Istighafardani, Vanidyatama dan Setyorini, Retno. 2017. Pengeruh Perceived Usefulness, Perceived Ease Of Use dan Perceived Risk terhadap Intention To Transact Pada Aplikasi Tiket.Com di Indonesia. Banking \& Management Review. 893-902.

Kasali, Rhenald. 2007. Membidik Pasar Indonesia: Segmentasi, Targetting, dan Positioning. Jakarta: Gramedia Pustaka Utama.

Kinnear, Thomas C., and Taylor, James R. 1987. Marketing Research. New York: McGraw-Hill.

Kim, Dan. J., Ferrin, Donald. L., and Rao, H, Raghav. 2007. A Trust-Based Consumer Decision Making Model in Electronic Commerce: The Role of Trust, Perceived Risk, and Their Antecedents. Decision Support Systems.44(2): 544-564.

Kotler, Philip., dan Keller, Kevin. Lane. 2012. Marketing Management. New Jersey: Pearson Education, Inc.

Kuncoro, Mudrajad. 2013. Metode Riset Untuk Bisnis dan Ekonomi. Yogyakarta: Erlangga.

Lai, E., and Wang, Zhaocheng. 2012. An Empirical Reaserch on Factors Affecting Consumer Purchasing Behavior Tendency during Online Shopping. IEEE. 583-586.

Lim, Nena. 2003. Consumer's Perceived Risk: Sources Versus Consequences.
Electronic Commerce Research Aplications. 216-228.

Lui, Hung. Kit and Jamieson, Rodger. 2003. TriTAM A Model For Integrating Trust and Risk Perception in BusinessTo-Consumer Electronic Commerce. $16^{\text {th }}$ Bled E-commerce Conference. 349-364.

Mcknight, D. Harrison., Choudury, Vivek., and Kacmar, Charles. 2002. The Impact of Initial Consumer Trust On Intention To Transact With A Website: ATrust Building Model. Journal of Strategic Information. 297323.

Mukherjee, Alvinandan and Nath, Prithwiraj. 2003. A Model Of Trust In Online Relationship Banking. International Journal Of Bank Marketing. 21(1): 5-15.

Pavlou, Paul. A. 2002. What Drives Electronic Commerce? A Theory of Planned Behavior Perspektif. Academy of Management Proceedings. 1-6.

Pavlou, Paul. A. 2003. Consumer Acceptence of Electronic Commerce: Intregeting Trust and Risk with the Technology Acceptence Model. International Journal Electronic Commerce. 7(3): 101-134.

Peter, J.P. and Ryan, M.J. (1976). An investigation of perceived risk at the brand level. Journal of Marketing Research. 13(2): 184-9.

Rizwan, Muhammad., Umair, Syed. M., Bilal, Hafiz. M., Akhtar, Mueen., and Bhatti, Muhammad, S. 2014. Deterninants of Custumer Itentions for Online Shopping: A Studi of Pakistan. Journal of Sociological Reaserch. 5(1): 248-272.

Budiyanto \& Dewi Pangestuning Utami; Integrasi Trust dan Technology Acceptance Model (TAM) dalam Intention to Transact 


\section{SEGMEN Jurnal Manajemen dan Bisnis \\ Volume 17 No 2 Juli 2021 \\ p-ISSN: 0216-938X e-ISSN: 2684-8414}

Sekaran, Uma dan Bougie, Roger. 2016. Research Method for Business a Skill Building Approach Seventh Edition. United Kingdom: John Wiley \& Sons.

Schiffman, Leon. G., dan Kanuk, Leslie. L. 2008. Perilaku Konsumen Edisi Ketujuh. Jakarta: PT. Indeks.

Sutomo, Devi. 2012. Pengeruh Perceived Usefulness, Perceived Ease Of Use dan Perceived Risk terhadap Intention To Transact pada Toko Online di Surabaya. 30-34.

Venkatesh, Viswanath., and Davis, Fred. D. 2000. A Theoritical Extension of the Technology Acceptance Model: Four Longitudinal Field Studies.
Management Science. INFORMS. 46(2): 186-204.

Wen, Chao., Prybutok, Victor. R., and Xu, Chenyan. 2011. An Integrated Model for Customer Online Repurchase Intention. Faculty Research and Creative Activity. 8.

Budiyanto \& Dewi Pangestuning Utami; Integrasi Trust dan Technology Acceptance Model (TAM) dalam Intention to Transact 